\title{
Thermal equity, public health and district cooling in hot climate cities
}

Terence H. Thomas Department of Engineering, Warwick University, Coventry, UK

Chris P. Butters Centre for Development and the Environment, Oslo, Norway

(corresponding author: chris@butters.no)

In urban environments, 'chemical' air pollution has long been of concern. Currently, 'physical' air pollution, in the form of excessive temperatures, is likely to impact public health even more, especially in cities with hot climatic conditions. The urban heat island effect (UHI) - whereby big-city air temperatures are already elevated by up to $7^{\circ} \mathrm{C}$ - is intensifying with urban growth and global warming. Overheating of cities is in addition inequitable, as it is predominantly caused by the rich and suffered by the poor. Heat waves are becoming more frequent and severe. Measures to combat UHI include improved urban design, improved technical efficiencies, reduced heat from vehicles, reduced consumption and palliative or emergency civil measures. A measure of exceptional interest is 'district cooling' (DC), the counterpart of the district heating widespread in temperate climates. DC offers economies of scale, higher-energy efficiency than air conditioning, lower climate emissions and other benefits. It is in fact almost the only way to actually counteract UHI, by removing heat from the urban environment, thus reducing the growing energy use and health impacts in hot climate cities. This paper surveys the current practice in DC and its potential benefits.

\section{Introduction}

In any high-density city there is necessarily much sharing of public space, services such as drainage and the very air in the city. 'Chemical' air pollution has long been of major concern; 'physical' pollution in the form of excessive temperatures is now impacting public health in many cities. That city air temperatures are elevated above those of the rural hinterland is well documented and is predicted to intensify with the densification of cities and global warming. Overheating of the urban environment is generally inequitable: it is predominantly caused by the rich and most suffered by the poor. Its main anthropogenic sources are vehicles and room-by-room air conditioning $(A C)$ resulting in emissions of thermal energy to the immediate street environment. Passive measures to combat high urban temperatures are as old as cities themselves. Active cooling, especially in the humid tropics, is more recent. The means of addressing the effects of excessive heat include improved architecture, optimal street layouts, 'blue-green' urban spaces that provide evaporative cooling, raising the 'coefficient of performance' (COP) of AC heat pumps, legislating to reduce heat release, meteorological warnings and providing emergency refuges. One might group these into passive measures of better urban and building design, active or supply side ones such as district cooling (DC), and mitigation ones like opening heat-wave refuges.

A measure of particular interest to municipal engineers is DC, the counterpart of the district heating long used in temperate cities. Even when only directly accessed by the relatively rich, DC has benefits for the urban poor and exhibits fewer inequities than classic 'building-by-building' AC.

The choice of space-cooling technology is currently influenced by cost, energy availability, concerns over worker productivity and human comfort, greenhouse gas emissions and several other factors. For 'thermal equity' to also be a serious factor, one would need to demonstrate four propositions, namely (Table 1).

Article published in Proceedings of the Institution of Civil Engeneers - Municipal Engineer https://www.icevirtuallibrary.com/doi/10.1680/imuen.17.00020 
Overheating can increase both morbidity and mortality. Heatinduced mortality mostly occurs during heat waves, as can be demonstrated using relatively simple data - such as temperature-related changes in daily 'deaths from all causes'. The demonstration of heat-induced morbidity requires greater statistical skill, and is disregarded in this paper. Avery large study from 164 cities in 36 countries (Mora et al., 2017) found that about $48 \%$ of the world's population would be exposed to deadly thresholds of heat for at least $20 \mathrm{~d}$ a year by 2100 - even with reduced climate emissions. This paper surveys the evidence of trends in the overheating of cities, the impact they have on mortality and what may be driving them. It then reports the current practice in DC, the prime candidate for reducing urban warming, and assesses its potential in its various forms.

\section{Urban 'thermal public health' in hot climates: history, trends and inequities}

High temperatures cause discomfort, especially if accompanied by high humidity. Pollution exacerbates this further. The complex relationship between comfort and temperature, humidity, clothing and activity has long been studied and standards have been developed for the globally massive AC industry (ANSI/ASHRAE, 2010). They do not however allow for the heat adaptation often exhibited by inhabitants of hot climate countries, especially those in the tropics. According to these standards, sustained temperatures exceeding $30^{\circ} \mathrm{C}$ are deemed to be uncomfortable or to result in low productivity. When air temperatures for many hours exceed human body temperature $\left(37^{\circ} \mathrm{C}\right)$, there can be danger of death, as evaporative self-cooling is impeded: it would fail completely if wet bulb temperature exceeded $37^{\circ} \mathrm{C}$. Dry-bulb temperatures exceeding $40^{\circ} \mathrm{C}$ are commonly experienced in tropical cities; $45^{\circ} \mathrm{C}$ peaks are not uncommon.

\section{Table 1. Propositions to support an accusation of significant urban thermal inequity}

\begin{tabular}{l} 
Number Proposition \\
\hline 1 Cities are warming rapidly, with hot climate cities in \\
particular getting dangerously hotter \\
A large fraction of the populations of these cities \\
continues to have no access to cooling in their \\
dwellings or workplaces \\
The cooling activities (AC) of the relatively rich \\
contribute significantly to urban warming \\
Urban warming is already a threat to public health, \\
with heat events that harm or kill significant numbers \\
of urban dwellers, in particular the poor
\end{tabular}

Farmers working in fields face mortality during heat waves, but generally rural dwellers have access to ventilated outdoor shading and hence can obtain some relief. Some urban dwellers also work outdoors, and others live and work indoors where solar radiation is less but air movement may be poor. Outdoor urban temperatures are significantly higher than rural ones. In most tropical countries, the number of people living in big cities, but without AC, constitutes a large fraction of the national population. Megacity growth in the next 15 years is projected to be concentrated within $25^{\circ}$ of the Equator and will increase the population experiencing extreme temperatures. The fraction of the world's megacities (pop >10 million) that lie in this hot zone is forecast to rise from $43 \%$ in 2000 to $56 \%$ in 2030 (UN WUP, 2014). Many of these cities lie in Asia.

Excessive urban heat is inequitable in its impact. The poor, who are not the generators of most of the urban heat, suffer disproportionately from it because they 
-- occupy crowded, low-quality housing and workplaces that are rarely shaded, insulated or well ventilated

-- have fewer or no household cooling amenities \& spend more time working or walking outdoors, on twowheelers or in non-air-conditioned vehicles \& spend more time overall in air pollution, which exacerbates the health impacts of heat

-- have less means, or permission, to shelter during heat waves

-- may have weaker defences against heat stress due to poor nutritional or health conditions.

The thermal conditions in a city may be considered as the superposition of the regional climate (e.g. as measured on the city's periphery), regional weather (short-term variations) and an urban supplement. This supplement causes urban heat island effect (UHI), expressed in ${ }^{\circ} \mathrm{C}$ urban-against-rural excess. Three factors are expected to cause urban temperatures to increase significantly. These are global warming, urban growth (and changes in urban form) and growing anthropogenic heat release. The weight to be assigned to these three is hard to estimate, but several studies indicate that global warming is the major component (Lauwaet et al., 2015). Each is in theory amenable to human control. This paper addresses only the last of these factors.

UHI has long been studied (Howard, 1815): it is complex and time varying. It is strongly influenced by the fraction of the city area that is low-albedo hardscape (Khare and Beckman, 2013). In megacities at low latitudes $\mathrm{UHI}$ currently averages around $3^{\circ} \mathrm{C}$, but with maximum values up to $10^{\circ} \mathrm{C}$ (Santamouris, 2015). A large Central Europe study (Musco, 2016) recorded that UHI is generally larger by night than by day. The same is however not always the case in other regions. Several Southeast Asian studies (Aflaki et al., 2017; Estoque et al., 2017; Singh, 2014; Takebayashi, 2015), show UHI to be higher (e.g. by $3^{\circ} \mathrm{C}$ ) over impervious surfaces than in urban green spaces, which have a definite and well documented cooling effect. Although attempts have been made to model heat fluxes (Cheshmehzangi and Butters, 2017; Musco, 2016) between buildings, streets, air and sky, our understanding the impact on UHI of extra anthropogenic energy releases is far from comprehensive. Recent studies (Boehme et al., 2015) suggest that the anthropogenic heat injected (per square metre summed over $24 \mathrm{~h}$ ) into the central business district (CBD) of a tropical city such as Singapore may exceed $100 \mathrm{~W}$ and even approach that received from solar radiation. Studies indicate that warming and extreme heat events due to urbanisation and increased energy consumption are simulated to be as large as the impact of doubled $\mathrm{CO} 2$ in some regions, and climate change increases the disparity in extreme hot nights between rural and urban areas (McCarthy et al., 2010).

$\mathrm{UHI}$ is becoming a major concern and is very well documented but less so in developing countries, where many of the fastest growing and hottest cities lie. Heat events are having major effects; about 70000 excess deaths resulted from the European heat wave of 2003 (Robine et al., 2008), of these over 2000 in England (ONS, 2005). Similar excess mortality is documented in many major medical studies - even in quite temperate climates.

The use of conventional active cooling in hot climate cities has been spreading downwards from the rich towards the middle classes. Its uptake is expanding rapidly, with estimates that $70 \%$ of Chinese urban homes now have some installed AC. The average indoor conditions in Asian megacities are therefore possibly improving, although many who have some AC cannot afford to use it continuously or in every room. It is not clear whether this expansion of AC will reach the poorest urban dwellers within say 20 years. Even if it does so, by using current cooling technologies, the outdoor urban climate will be further worsened.

The study of the relationship between 'excess mortality' and heat waves, although noted in the early nineteenth century, accelerated after the 1995 Chicago heat wave (Klinenberg, 2003), but was strongly 
biased towards the United States and Europe. Interpreting mortality statistics requires careful epidemiological techniques (Basu and Samet, 2002). Extreme weather events certainly cause the daily death rate to rise (Gasparini and Armstrong, 2011; Son et al., 2012). Excess mortality per day correlates mainly with peak temperatures but also depends on factors such as the age and wealth of the population.

A study of one heat wave, in Allahabad 2010, where temperatures exceeded $45^{\circ} \mathrm{C}$ for $4 \mathrm{~d}$ (Azhar et al., 2014) showed a $40 \%$ increase in the May mortality over the average of the previous and following years. Figure 1 shows the dramatic short-term impact with an excess of around 1300 deaths over a $13 \mathrm{~d}$ period. Despite some cultural adaptation, India is particularly vulnerable to heat wave mortality and warning systems have been started to reduce fatalities (GoINDMA, 2016). The country has formalised definitions of 'heat wave' and 'severe heat wave' and uses 41 and $54^{\circ} \mathrm{C}$ as thresholds of 'danger' and 'extreme danger', respectively. It is noted that '(outdoor) workers, homeless people and the elderly constitute the majority of heat wave casualties in India'.

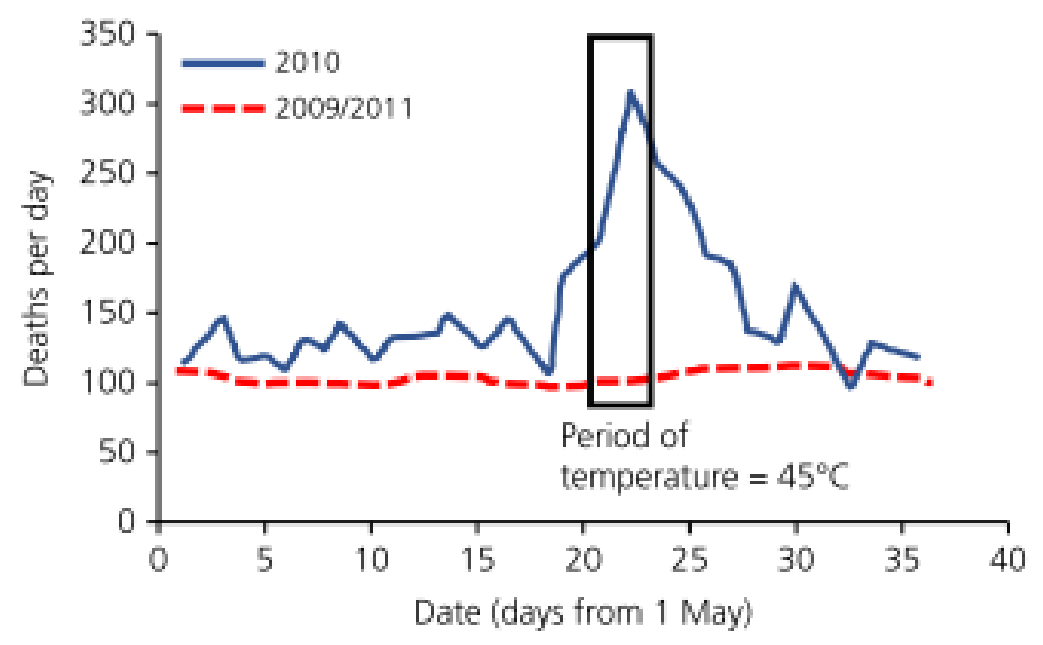

Figure 1. Daily deaths from all causes in a severe heat wave in Allahabad, May 2010. The year 2010 is compared with the $7 \mathrm{~d}$ running average for 2009 and 2011. Source: data from Azhar, 2014

It would seem that at present heat-induced morbidity, averaged over several years, is nowhere the major cause of death. A notorious historical example - the 'Black Hole of Calcutta' event in 1756 - was more likely one of asphyxiation than of extreme temperature. The excess deaths during the heat wave shown above, represent only $0.3 \%$ of Ahmedabad deaths in that decade. However, crude correlations between mortality and temperatures suggest a $1^{\circ} \mathrm{C}$ rise in the mean summer temperature of an already hot city might result in a $0.4 \%$ rise in mortality (Zanobetti and Schwartz, 2008). A $1^{\circ} \mathrm{C}$ rise in peak temperature might increase daily mortality by much more (Kim et al., 2010) for the duration of a heat wave.

Global temperature rise currently averages around $0.17^{\circ} \mathrm{C}$ per decade (NOAA, 2015), with the rate for the tropics less than that for the whole globe. However, urban temperature changes entail the superposition of changes in UHI on those due to climate change. Tropical cities are currently getting markedly hotter. Even small increases in the mean and variance of a temperature distribution can be expected to disproportionately amplify the occurrence of extreme temperatures (Climate Communication Org, 2017). In ten tropical Asian megacities, the average of peak temperatures for $2013-2016$ was $1.3^{\circ} \mathrm{C}$ higher than the corresponding average for 2009-2012. The rise per decade since 1948 has been fully $0 \cdot 25^{\circ} \mathrm{C}$ per decade in Singapore for example (MSS, 2016). The attribution of this rise to urban change/growth and extra heat Article published in Proceedings of the Institution of Civil Engeneers - Municipal Engineer https://www.icevirtuallibrary.com/doi/10.1680/imuen.17.00020 
release, respectively, needs further research. Such research should be particularly concentrated on Asia as having the largest number of people living in hot megacities.

The preceding paragraphs have offered some evidence to support the first three propositions of Table 1. Proposition 4 requires urgently needed studies in hot climate cities in developing countries, for there is no doubt that the poor are most exposed to the effects of $\mathrm{UHI}$, and that excess mortality in the coming years will be very considerable.

More generally, rising temperatures are causing extreme heat waves to move higher up the list of 'natural disasters' needing compensatory public action. There is also growing awareness of the linkage between high temperatures and lethal air pollution.

\section{Physics of cooling and reduction of heat rejection into an urban environment}

Cooling a building is more complex than heating it, and per joule of energy moved, it is generally more expensive. To move a quantity QA of heat from place A 'uphill' to a hotter place B, it has to be 'pumped' using either some work Wor (less commonly) a supply of heat QC from an even hotter source $C$. In the equilibrium diagram below, all energy flows could be designated in megajoules or in kilowatt-hours per 24 $h \mathrm{~d}$, as the thermal inertia of buildings allows meaningful $24 \mathrm{~h}$ averaging.

Figure 2 is a much simplified model of urban heat flows at equilibrium. If there were no $A C, Q A=Q C=Q B=0$ and street temperature TS would assume some datum value TSO determined by climate. When AC is switched on to cool the building interiors, QA, QC and QB take on positive values, one consequence of which is the emission of QBL-Q1 to the streets causing their temperature TS to rise. This rise is amplified by positive feedback until a new equilibrium is reached with a higher value for TS (=TSAC $>$ TSO) The ratio QA:QC (heat extracted/driving energy) is the COP of the cooling system. For heat-driven space cooling using modern sorption technology, COP heat has a value of about 1.0. 'Work' W (usually in electrical form) rather than heat QC is commonly used to drive the heat pumping, and COP work, now defined as QA/W, is much better - typically 3 to 5 .

To reduce this rise in TS there are several options including

-- setting the target indoor temperature (TB) higher, especially during heat waves

-- reducing the heat inflow $(\mathrm{Q} 1+\mathrm{Q} 2)$ by architectural means and good urban design

-- using better on-site technology with a higher COP \& avoiding heat-driven cooling (very low COP) \& diverting the reject heat $\mathrm{QB}$ away from the streets by sending it outside the city as represented by the dashed line in Figure 2.

This last option, achieved by DC is much the most effective, as it results in a net flow of heat from the streets to the buildings; and from the city to outside the city limits. 


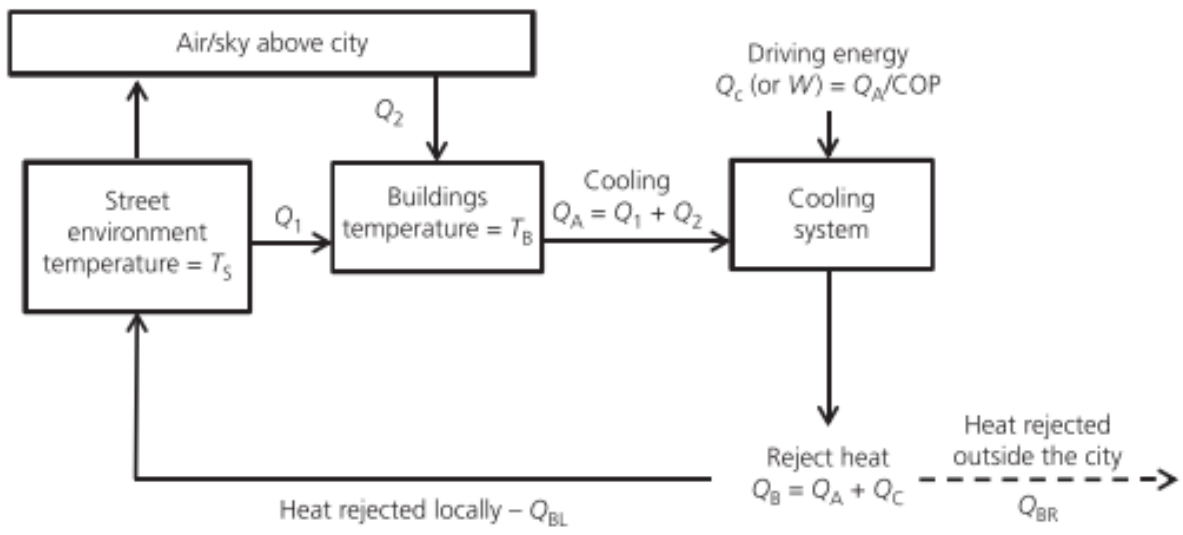

Figure 2. Energy flows at equilibrium in a city with $\mathrm{AC}$ flows are in $\mathrm{kWh} / \mathrm{d}$. The net heat transferred from buildings to streets $=Q_{\mathrm{BL}}-Q_{1}$

\section{Towards more equitable and efficient cooling of cities}

The preceding sections of this paper have argued that cities are getting hotter, dangerously so, partly due to fast-rising $\mathrm{UHI}$, and that ever-increasing building-by-building $\mathrm{AC}$ is inequitable and to some extent selfdefeating. As with winter heating in higher latitudes, achieving efficient urban cooling should start with better design of buildings and urban districts to reduce the need for cooling. This is extensively covered in the literature. This paper has instead focused on the benefits and feasibility of replacing building-bybuilding AC with DC whose benefits include achieving greater 'thermal equity'.

Essentially, the need is to remove the sources of heat from the inner city. This is what DC systems offer. By moving the energy production outside the city they offer the unique feature of reducing UHI, thus impacting positively on environment as well as on comfort and public health. DC solutions also offer higher efficiencies, economies of scale, flexibility as to energy sources, reduced greenhouse gas (GHG) emissions, and lower long-term costs when compared with AC.

The term 'district energy system' applies quite broadly on a scale ranging from a housing estate or industrial park to whole city districts. Many also provide electricity in combined heat and power (CHP) systems. They may be developed and run by the public or private sector. While district heating (DH) is widespread in temperate climates, DC is less well known although large-scale systems have existed for some years. District energy systems can provide winter heating, summer cooling or both. In addition, electricity is a high-quality energy carrier (exergy), which unless generated by renewables implies high GHG emissions. In contrast to electricity-driven AC, DC thus supplies energy in the end-use form required: lowtemperature cold water or air.

The first DH dates back to 1877 in New York; the first DC was built in Colorado in 1930. An initial wave of interest in seawater cooling systems (SWAC) occurred in the 1970s (ANLTJ, 1977), and interest continued in locations including California and Hawaii (Radspieler et al., 1999; SoH, 2002). DC systems are not unknown in industrialised countries; many continental cities have extreme winters and extreme summers; and cities as far north as Scandinavia now have considerable summer cooling needs too. In Sweden, where district energy has long been widespread, around $25 \%$ of cooling is already supplied by DC (Dalin, 2012). In Europe as a whole, however, the market share of DC for cooling is under 2\% (EU Euroheat and Power Ecoheatcool, 
2006). In hot climate cities in developing countries, where the need is most evident, DC is as yet even less applied.

There is a drive for district energy systems, promoted by the EU (EU European Commission RESCUE project, 2015), IEA (IEA, 2013), UNEP (UNEP, 2013) and industry organisations, including the International District Energy Association IDEA (IDEA, 2015). DC is found in both hot-humid climates such as in Asia, and hot-dry climates such as the Gulf states (Berbari, 2009; Empower, 2016). There is considerable research on DC in China (Gong and Werner, 2014); a study for a combined DC/DH system for the coastal city of Dalian (Zhen et al., 2007) concluded by indicating high profitability. Studies encompass both water-based and underground cooling (Song et al., 2007). In the hot-humid tropics, there are large systems in Hong Kong and Singapore (Koon et al., 2007; Lo et al., 2014) as well as Malaysia. Singapore has one of the most ambitious DC systems covering to date around 3 million $\mathrm{m} 2$ of buildings with several hundred $\mathrm{MW}$ of cooling capacity (Kee, 2010; Mulchand, 2013) (Figure 3).

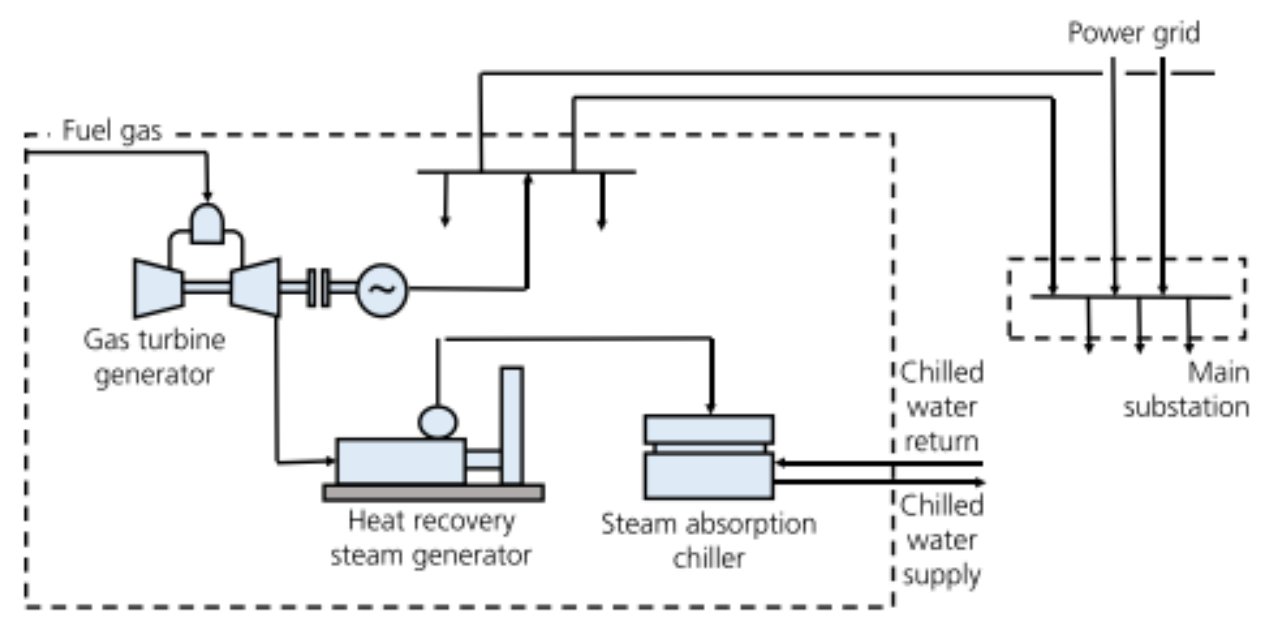

Figure 3. Schematic representation of typical DC system layout. Source: Danny Tam Hong Khai

\section{Energy sources and sinks for DC}

Most conventional AC takes in air at ambient temperature and cools it. The economics and efficiency of cooling are far better given a source that is cooler than ambient air. Natural sources include the ocean, lakes, rivers and the underground. Ecosystems are significantly affected only where very large energy plants reject the waste heat to a relatively small recipient. Water bodies are generally some degrees cooler than the ambient air in hot climates - and warmer in winter. In Paris, the DC system uses the River Seine both for summer cooling and, combined with other sources, for winter heating. It now provides over 400 GWH of cooling, with average GHG emissions of only $35 \mathrm{kgCO} e / \mathrm{kWh}$ of cooling (ClimEspace, 2013; GDFSuez, 2016).

Seawater-based air conditioning (SWAC) utilises cold ocean water, where temperatures of around $6^{\circ} \mathrm{C}$ can be obtained at 600-700 m depth. Cool fresh water is then distributed to the end users in a secondary circuit (Makai Ocean Engineering, 2016). In northern latitudes, oceans are cold at much shallower depths; large combined DH/DC systems exist in major Baltic cities such as Stockholm, Tallinn and Helsinki (Hani and Koiv, 2012; Riipinen, 2013). Lake-sourced DC projects exist in North America including the Cornell project described below and a large system in Toronto (Enwave, 2010). Lakes being fresh water, offer the added advantage that the system simultaneously provides city drinking water. Lakes also have stratification profiles that may offer cold water at shallower depths. 
Aquifers and the underground are also used; the underground can have a useful temperature differential and serve as a source of cold or heat. It can also be artificially cooled, as in central Berlin, which has a large seasonal energy storage system: cold water is pumped down to cool the underground during winter in order to provide cooling the following summer, and heat is pumped down in summer to another part of the underground to form a heat store for the following winter (Sanner et al., 2005).

While many of today's DC systems operate with gas, the energy source can be switched from the presentday fossil fuels to renewables.

\section{The Cornell example}

The DC system of Cornell University in the United States (Ashrae, 2016; Makai Ocean Engineering, 2016; Peer and Joyce, 2002), engineered with Hawaii-based company Makai Ocean Engineering, has operated since 2000. Essentially, any large body of deep water provides a nearly free cooling source; the energy required for pumping and distribution is relatively small. Cold water at around $4^{\circ} \mathrm{C}$ is pumped from a depth of $76 \mathrm{~m}$ from Lake Cayuga in HDPE pipes of $1.6 \mathrm{~m}$ diameter. A secondary circuit distributes cooling water to the 300 campus buildings. With a capacity of around $75 \mathrm{MW}$, efficiency is as high as $0.1 \mathrm{~kW} / \mathrm{t}$ of cooling delivered. This project illustrates the key considerations for DC: proximity of a large natural cold source; economies of scale; supply to many buildings evening out load demand; and few environmental impacts to lake or marine ecology. Impacts are reduced in particular by isothermal return - releasing the warmer return water to a layer of corresponding temperature in the lake. Compared to conventional cooling, the project reduces electricity requirements by no less than $87 \%$, over 20 million $\mathrm{kWh}$ annually; as well as annual reductions of $56000 \mathrm{t}$ of $\mathrm{CO} 2$ emissions, $400 \mathrm{t}$ less sulfur oxides, $55 \mathrm{t}$ less NOx; and eliminating the need for about $40 \mathrm{t}$ of CFCs (Figure 4).

Large SWAC systems with similar technology are in operation in locations, including Hawaii and Pacific islands, which have deep oceans nearby. Many coasts have shallow continental shelves that render SWAC unfeasible; but there are a considerable number of cities with deep ocean water in proximity. These systems can be very profitable and simultaneously reduce climate emissions and primary energy use by a factor of $70 \%$ or more.

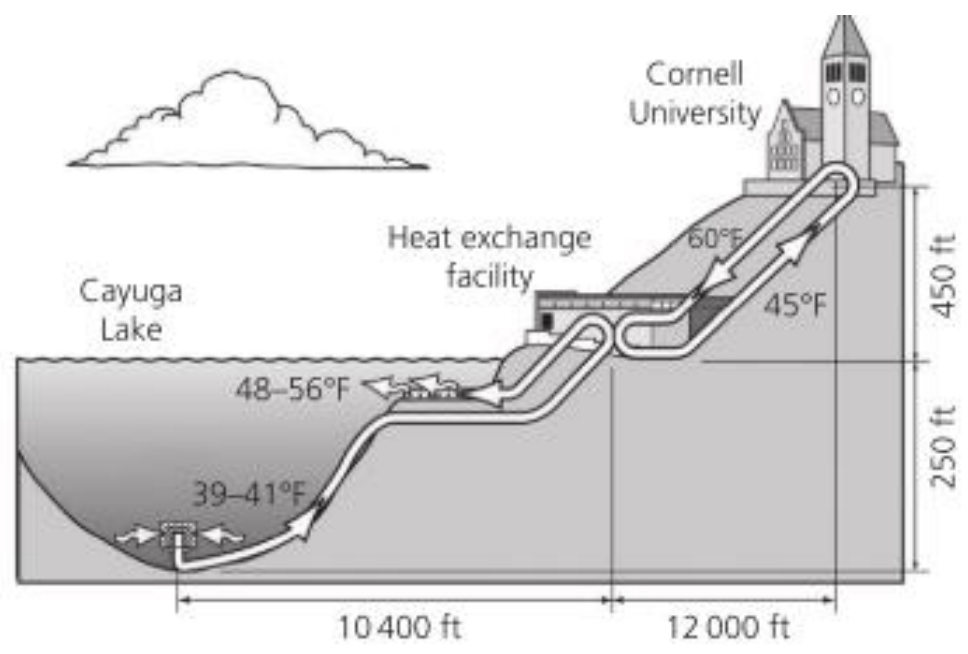

Figure 4. Comell University campus, USA: the Cayuga Lake based DC. Source: Jon Reis/Cornell University

DC is now spreading somewhat in countries such as Malaysia, with systems providing cooling and often also electricity to urban districts, campuses and industrial parks. The Asian Development Bank reported 
that Malaysia could triple its DC industry (The Star, 2013). Many of the DC plants employ thermal energy storage (TES) in ice or cold water (Siron and Haron, 2015), advantageous if, as in Malaysia, there are offpeak night tariffs for electricity. The Petronas Technological University system is a typical example of a cogeneration system that utilises waste heat from a CHP gas turbine generating electricity, converting residual steam to chilled water in a steamabsorption chiller. The chilled water is distributed to buildings at $6^{\circ} \mathrm{C}$ and returned at around $13^{\circ} \mathrm{C}$. This process enhances the overall efficiency of cogeneration from around $40 \%$ to nearly $70 \%$, as well as reducing waste heat to the environment, and reduces GHG by around $28 \%$ (Nordin et al., 2013).

\section{Advantages, requirements and barriers}

The key advantages of DC are higher efficiencies and economies of scale. Given this alone, the application potential is very wide. It does not exclude projects of modest size such as a university campus or a tourist complex. DC systems offer longer life than small AC units, 25-40 years as opposed to 10. Typically, the large systems offer 15-30\% lower overall energy use (and hence climate emissions) than conventional AC. SWAC in particular offers large advantages. Notably, DC also saves space and cost for the individual buildings since they eliminate much of the need for plant rooms and equipment. DC provides cooling without vibrations or noise. Further, DC permits far more efficient management and maintenance than is typically the case with small-scale cooling installations, not least in developing countries.

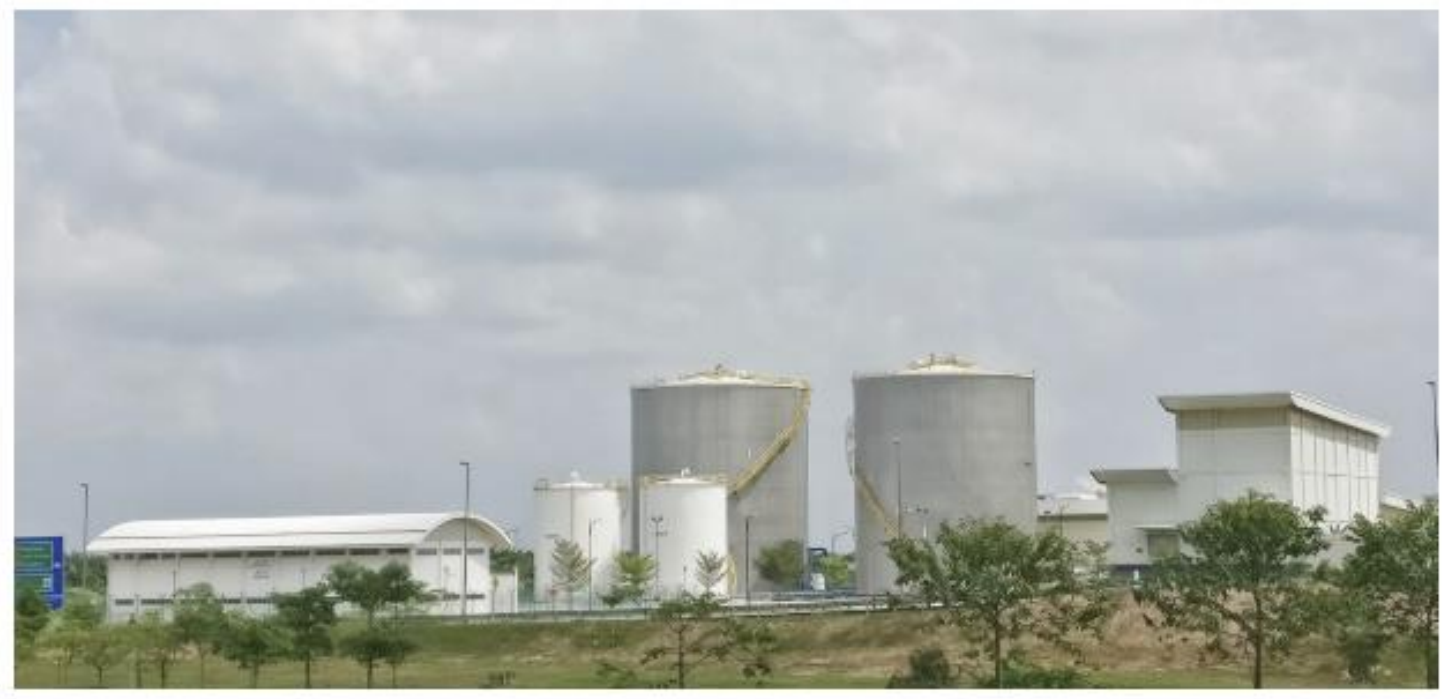

Figure 5. DC plant at Kuala Lumpur International Airport (KLIA). Source: Danny Tam Hong Khai

As DC systems employ familiar components such as pumps, piping and heat exchangers, challenges are not primarily technical but ones of energy policy, urban planning and financing (Cheshmehzangi and Butters, 2017). Their economic feasibility depends on energy prices and specific urban contexts as well as considerations of energy security, robustness and environment. Other key factors are the end-use energy density - they are obviously less economical in suburbs with long piping distances distributing little energy - and the physical context, clearly best being simple street layouts in geologically easy terrain. Due to high capital costs, it is normally mandatory for all buildings within a DH/DC area to connect to the system. This implies a possible conflict between urban planning and building planning, noted briefly below.

DC provides cooling with far lower operational costs, but high capital cost. This is often a barrier in developing countries where cities cannot provide the financing. However, district energy can be profitably financed and run by private sector energy service companies (ESCOs). For example in a large development 
in Nydalen in Oslo, Norway, the private developer realised that building the energy supply based on underground heat and running it as an ESCO offered a new business opportunity (Energi 21, 2010). Countries such as China have the advantage of strong central planning; but in many low-income countries, urban development tends to be small scale and there is little or no legislation, planning capacity or governance to implement large-scale projects.

Large DC projects provide far lower long-term costs, typically 15-20\% cheaper energy, and GHG emissions at least some $25 \%$ lower even in conventional fossil fuel powered CHP plants (Nordin et al., 2013) such as Figure 5. Hence, DC is starting to spread in Asia (Figure 6). Given financing and good planning, policy leadership is needed but no special subsidies; DC is simply becoming the best option. The feasibility of DC will increase with rising energy prices and climate emission restrictions. Retrofitting district energy is onerous in existing cities; however, the fact that $\mathrm{DH}$ is nevertheless spreading fast even in existing cities indicates that both DH and DC are increasingly attractive. DC is of most relevance for the rapidly expanding cities in developing countries, where the infrastructure can be integrated from the start. Those cities are locking themselves into future energy and climate burdens, where overlooking DC represents a huge missed opportunity.

\section{Equity and city planning}

DC has an important equity dimension. In addition to cooler home environments, workers in hot climate developing countries often have very poor conditions. In Malaysian factories, typically $40 \%$ of total power consumption is for cooling which is needed all year round. Many factories use old, inefficient AC equipment (Pacific Consultants Co., Ltd. et al., 2014). DC thus offers a win-win for both workers and owners. In cities worldwide, UHI combined with pollution is becoming a major issue of public health; vulnerable groups include not only the poor but the elderly and the young, as well as a rising number of people with asthma and other respiratory problems.

Some broader considerations may be mentioned. What makes

a healthy or 'sustainable' city? Today's popular paradigm of 'compact cities' is not unproblematic; while it offers efficient concentration of energy and mobility solutions, it also implies a concentration of negatives, including high land prices, congestion, noise, pollution and UHI effects (Cheshmehzangi and Butters, 2014).

There is a need to integrate urban planning and energy planning. Cooling with AC in individual buildings is inefficient and worsens UHI. In hot climates, energy-conscious architectural design can reduce cooling needs, as can good city planning with green spaces and street configurations that maximise

urban ventilation. There are many options using natural or 'passive' cooling to create a comfortable indoor climate. However, these are fewer in hot-humid climates where 'passive' solutions can not eliminate entirely the need for added 'active' cooling technology for parts of the year. And it is those hottest periods where adding AC-related waste heat to the city air has the worst effects.

There is a potential conflict between cooling solutions at the level of individual buildings against solutions at the level of the urban planning. Which level should be prioritised, and under what conditions? Solutions at micro, meso or macro level involve differing interests, decision makers and stakeholders. There is a relatively little focused trade-off between efficient buildings and efficient large-scale supply systems such as DC (and, in cold climates, DH). Profitability is best at high urban densities - and also where the buildings are not energy efficient but have high-energy demands. A little discussed consequence is that district energy systems could thus have the effect of disincentivising low-energy buildings. 


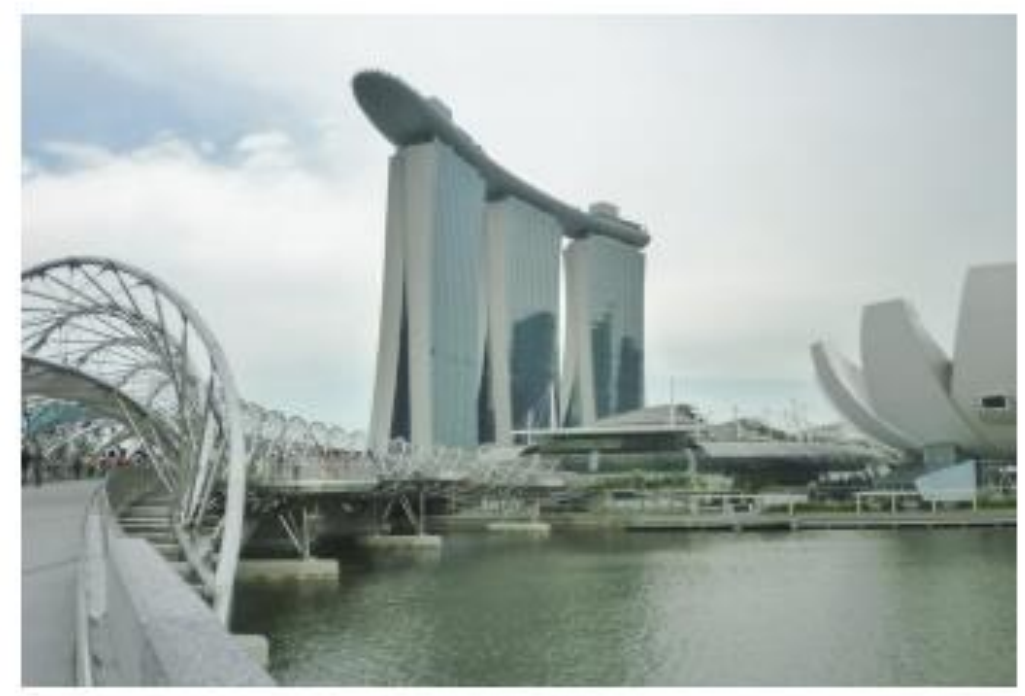

Figure 6. The Marina Bay Sands district, Singapore has one of the largest DC systems. Source: Ali Cheshmehzangi

\section{Conclusions}

Urbanisation continues apace and the urban fraction of world population has reached $55 \%$. Hot climate megacities are dominating this growth. The UHI effects and peak temperatures in particular, are rising strongly. More intense heat waves are projected to increase the already significant heat-related mortality. Moreover, conventional space cooling (AC) is inequitable: when practised by richer citizens it worsens the thermal environment of the urban poor by injecting more heat into the city. UHI and thermal public health should now be a major factor in city planning and in energy policy decisions, which should be directed more towards solutions at the district scale. Efficiency improvements in AC technology (higher COPs) can at best only slow the growth of urban heat and GHG emissions.

There are strong arguments in favour of promoting DC, being almost the only way to remove heat from the city environment. DC offers a range of other advantages including reduced primary energy use, lower GHG emissions and lower longterm costs. DC is applicable to business and industrial as well as residential districts. It can enhance equity and ameliorate urban living qualities for all, but especially for low-income groups, who often live and work in poor conditions, cannot afford amenities such as AC, and must often spend much time outdoors in their city. This applies particularly to developing countries. Very large opportunities for sustainable development are being missed through DC-type energy solutions not being integrated into hot climate cities.

\section{Acknowledgement}

This document is an output from a project co-funded by UK aid from the UK Department for International Development (DFID), the Engineering \& Physical Science Research Council (EPSRC) and the Department for Energy \& Climate Change (DECC) for the benefit of developing countries. The views expressed are not necessarily those of DFID, EPSRC or DECC.

\section{REFERENCES}

Article published in Proceedings of the Institution of Civil Engeneers - Municipal Engineer https://www.icevirtuallibrary.com/doi/10.1680/imuen.17.00020 
Aflaki A, Mirnezhad M, Ghaffarianhosseini A et al. (2017) Urban heat island mitigation strategies: a state-of-the-art review on Kuala Lumpur, Singapore and Hong Kong. Cities 62: 131-145, https://doi.org/10.1016/j.cities.2016.09.003.

ANLTJ (Argonne National Laboratory and Tracor Jitco) (1977) Feasibility ofa District Cooling System Using Natural Cold Water.US Department of Energy, National Technical Information Service, Lemont, IL, USA, Report.

ANSI/ASHRAE (American National Standards Institute/American Society of Heating, Refrigerating and Air-Conditioning Engineers) (2010) Thermal Environmental Conditions for Human Occupancy, Appendix 1. ANSI/ASHRAE, Atlanta, GA, USA.

Azhar GS (2014) Heat-related mortality in India: excess all-case mortality associated with the 2010 Ahmedabad heat wave. Public Library ofScience PLoS One 9(3): e91831.

Basu R and Samet JM (2002) Relation between elevated ambient temperature and mortality: a review of the epidemiologic evidence. Epidemiological Reviews 24(2): 190-202.

Berbari G (2009) History ofDistrict Cooling in the Middle East. United Arab Emirates. See http://www.dcproeng.com/article.php? article=144 (accessed 22/03/2016).

Boehme P, Berger M and Massier T (2015) Estimating the building based energy consumption as an anthropogenic contribution to urban heat islands. Sustainable Cities and Society 19: 373-384, https://doi.org/10.1016/j.scs.2015.05.006.

Cheshmehzangi A and Butters C (2014) The effects of improved built form on urban cooling: review of passive strategies and urban design case studies. SEE 2014, Bangkok. See https://warwick.ac. uk/fac/sci/eng/elith/publications/all_publications/elith-xw06.pdf (accessed 23/01/2018).

Cheshmehzangi A and Butters C (eds) (2017) Designing Cooler Cities: Energy, Cooling and Urban Form: the Asian Perspective. Palgrave Series in Asia and Pacific Studies, Palgrave MacMillan, Singapore, Singapore.

ClimEspace (2013) Discover District Cooling and Combine Efficiency with Urban Ecology. ClimEspace, Paris, France. See http://www. climespace.fr/eng/The-company/Press-room/Brochures (accessed 23/03/2015).

Dalin P (2012) Free cooling: natural cooling is crucial for a successful district cooling development. Euroheat and Power Annual Conference, Copenhagen, Denmark.

Empower (2016) Emirates Central Cooling Systems Corporation. EMPOWER, Dubai. See http://www.wmpower.ae (accessed 20/06/2016).

Energi 21 (2010) Arbeidsgruppe for Geotermisk Energi, Innsatsgruppe Fornybar termisk energi. Forskningsrådet (The National Research Council), Oslo, Norway (in Norwegian).

Enwave (2010) Deep Lake Water Cooling: Keeping Toronto Cool. Enwave District Energy, Toronto, Canada. See http://www.enwave. com (accessed 25/10/2017).

Estoque RC, Murayama Y and Myint SW (2017) Effects of landscape composition and pattern on land surface temperature: an urban heat island study in the megacities of Southeast Asia. Science of the Total Environment 577: 349-359, https://doi.org/10:1016/ j.scitotenv.2016.10.195.

EU Euroheat and Power Ecoheatcool (2006) Possibilities with More District Cooling in Europe. Work Package 53. EU Euroheat \& Power Ecoheatcool, Brussel, Belgium. See http://www.ecoheatcool.org (accessed 23/01/2018).

EU European Commission RESCUE project (2015) Best Practice Examples ofDistrict Cooling Systems. EU European Commission RESCUE project, Brussels, Belgium. See

http://ec.europa.eu/energy/intelligent/projects/en/projects/rescue (accessed 00/00/0000).

Gasparini A and Armstrong B (2011) The impact of heat waves on mortality. Epidemiology 22(1): 68-73.

Article published in Proceedings of the Institution of Civil Engeneers - Municipal Engineer https://www.icevirtuallibrary.com/doi/10.1680/imuen.17.00020 
GDF-Suez (2016) ClimEspace, 1st European District Cooling System, Sheet 7. GDF-Suez, Paris, France. See http://www.paris-green.com (accessed 22/04/2016).

GoINDMA (Govt. of India National Disaster Management Authority) (2016) Guidelines for Preparation ofAction Plan Prevention and Management ofHeat-Wave. Govt. of India National Disaster Management Authority, Delhi, India.

Gong M and Werner S (2014) District Heating Research in China. Svensk Fjärrvärme AB, Stockholm, Sweden.

Hani A and Koiv TA (2012) The preliminary research of sea water district heating and cooling for Tallinn Coastal Area. Smart Grid and Renewable Energy 3(3): 246-252.

Howard L (1815) The Climate ofLondon, Deduced from Meteorological Observations, Made at Different Places in the Neighbourhood ofthe Metropolis. London, UK.

IDEA (International District Energy Association) (2015) Case Study Series: College Campus CHP, Cornell Lake Source Cooling System. IDEA, Westborough, MA, USA. See http://www. sustainablecampus.cornell.edu/initiatives/lakesource-cooling (accessed 22/07/2017).

IEA (International Energy Agency) (2013) Implementing Agreement on District Heating and Cooling Including Combined Heat and Power. IEA, Paris, France. See http://www.iea-dhc.org/the-technology. html20133 (accessed 23/01/2018).

Kee TP (2010) District Cooling as an Energy and Economically Efficient Urban Utility-Its Implementation at Marina Bay Business District. Singapore District Cooling Pte Ltd, Singapore.

Khare A and Beckman T (eds) (2013) Mitigating Climate Change: The Emerging Face ofModern Cities. Springer, Singapore.

Kim H, Ha J and Park J (2010) High temperature, heat index, and mortality in 6 major cities in South Korea. Archives of Environmental and Occupational Health 61(6): 265-270.

Klinenberg E (2003) Heat Wave: A Social Autopsy ofDisaster in Chicago. University of Chicago Press, Chicago, IL, USA.

Koon CH, Sing SJ, Soon NY, Chua TL and Boon NC (2007) Indirect Seawater Cooling and Thermal Storage System in Changi Naval Base, Singapore. See http://www.dsta.gov.sg/docs/publications.../ dh2007 (accessed 24/03/2015).

Lauwaet D, Hooyberghs H, Maiheu B et al. (2015) Detailed urban heat island projections for cities worldwide: dynamical downscaling CMIP5 global climate models. Climate 3(2): 391-415.

Lo A, Lau B and Cheng V (2014) Challenges ofDistrict Cooling System (DCS) Implementation in Hong Kong. Arup Hong Kong, SB14, Barcelona, Spain.

Makai Ocean Engineering (2016) Personal correspondence 2016 and 2017. See https://www.makai.com (accessed 24/01/2018).

McCarthy M, Best M and Betts R (2010) Climate change in cities due to global warming and urban effects. Geophysical Research Letters 37(9): L09705.

Mora C, Dousset B, Caldwell I et al. (2017) Global risk of deadly heat. Nature Climate Change 7: 501-506, https://doi.org/10.1038/ nclimate3322.

MSS (Meteorological Service Singapore) (2016) The Meteorological Service Singapore Inaugural Annual Climate Assessment Report. MSS, Singapore. See http://www.weather.gov.sg/mss-releasesinaugural-annual-climateassessment-report-for-singapore-andlaunches-mobile-weather-app/ (accessed 22/06/2017).

Mulchand A (2013) Singapore has world's largest district cooling plant. The Straits Times, 24 November. See http://www.asiaone. com/singapore/spore-has-worlds-largest-district-cooling-plant (accessed 22/07/2017).

Article published in Proceedings of the Institution of Civil Engeneers - Municipal Engineer https://www.icevirtuallibrary.com/doi/10.1680/imuen.17.00020 
Musco F (ed.) (2016) Counteracting Urban Heat Island Effects in a Global Climate Change Scenario. Springer Open, Basel, Switzerland.

NOAA (National Oceanic and Atmospheric Administration) (2015) National Center for Environmental Information. State ofthe Climate: Global Analysis for 2016. NOAA, Singapore. See http://www.ncdc.noaa.gov/sotc/global/201613 (accessed 11/06/2017).

Nordin A, Buyamin N, Amin M et al. (2013) Evaluation of carbon dioxide emission using energy analysis approach: a case study of a district cooling plant. International Journal ofComputer and Electrical Engineering 5(3): 284-287.

Pacific Consultants Co., Ltd., Fuji Electric Co., Ltd. and Oriental Consultants Co., Ltd. (2014) Study on the HighlyEfficient District Heating and Cooling System for the High-Tech Park in Iskandar. Pacific Consultants Co., Ltd., Fuji Electric Co., Ltd. \& Oriental Consultants Co., Ltd., Japan.

Peer T and Joyce WS (2002) Lake-source cooling. Ashrae Journal 44(4): 37-39.

Radspieler A, Xu P and Haves P (1999) Seawater Source Cooling for Air Conditioning Commercial Buildings. California Energy Commission, PIER Program CEC-500-99-013, Lawrence Berkeley National Laboratory, Berkeley, CA, USA.

Riipinen M (2013) Modern District Heating and Cooling Systems. Clean Energy Ministerial CHP/DHC Working Group, International Energy Agency CHP/DHC Collaborative Joint Workshop, Helsinki, Finland.

Robine JM, Cheung SLK, Le Roy S et al. (2008) Death toll exceeded 70,000 in Europe during the summer of 2003. Comptes Rendus Biologies 331(2): 171-178.

Sanner B, Kabus F, Seibt P and Bartels J (2005) Underground thermal energy storage for the German parliament in Berlin, system concept and operational experiences. Proceedings ofthe World Geothermal Congress 2005, Antalya, Turkey.

Santamouris M (2015) Analyzing the heat island magnitude and characteristics in one hundred Asian and Australian cities and regions. Science ofthe Total Environment 512: 582-598, https://doi.org/10.1016/j.scitotenv.2015.01.060.

Singh RB (ed.) (2014) Urban Development Challenges, Risks and Resilience in Asian Megacities. Springer, Tokyo, Japan.

Siron M and Haron MH (2015) Energy and economic assessment of district cooling system in Malaysia. Science \& Engineering Technology National Conference 2015. Universiti Kuala Lumpur, Selangor, Malaysia. See https://www.researchgate.net/profile/ Mohd_Siron/publication/303806280_Energy_and_economic_ assessment_of_district_cooling_system_in_Malaysia/links/57541c5a08ae10d93378fc46/Energy-and-economicassessment-ofdistrict-cooling-system-in-Malaysia.pdf (accessed 14/01/2018).

SoH (State of Hawaii) (2002) Sea Water District Cooling Feasibility Analysis for the State ofHawaii. Department of Business, Economic Development \& Tourism's (DBEDT) Energy, Resources, and Technology Division, Hawaii, HI, USA.

Son JY, Lee JT, Anderson GB and Bell ML (2012) The impact of heat waves on mortality in seven major cities in Korea. Environmental Health Perspectives 120(4): 566-571.

Song YH, Akashi Y and Yee JJ (2007) Effects of utilizing seawater as a cooling source system in a commercial complex. Energy and Buildings 39(10): 1080-1087.

Takebayashi H (2015) Improvement Measures ofUrban Thermal Environment. Springer, Cham, Switzerland.

The Star (2013) http://www.thestar.com.my/business/businessnews/2013/10/23/ Malaysia, see also South East Asia Energy Efficiency Project, http://www.adb.org/projects/46914014/main (accessed 25/10/2017).

UNEP (United Nations Environment Programme) (2013) District Energy in Cities: Unlocking the Potential ofEnergy Efficiency and Renewable Energy (Highlights Annex 2) UNWUP. UNEP, Paris, France. See http://www.un.org/en/development/desa/news/.../worldurbanization-prospects-2014.html (accessed 25/10/2017).

Article published in Proceedings of the Institution of Civil Engeneers - Municipal Engineer https://www.icevirtuallibrary.com/doi/10.1680/imuen.17.00020 
UN WUP (United Nations, Department of Economic and Social Affairs, Population Division) (2014) World Urbanization Prospects: The 2014 Revision, Highlights. United Nations, New York, NY, USA, ST/ESA/SER.A/352.

Zanobetti A and Schwartz J (2008) Temperature and mortality in nine US cities. Epidemiology 19(4): 563-570.

Zhen L, Lin DM, Shu HW, Jiang S and Zhub YX (2007) District cooling and heating with seawater as heat source and sink in Dalian, China. Renewable Energy 32(15): 2603-2616. 